\title{
THE EFFECT OF BRAND EXPERIENCE ON BRAND TRUST AND BRAND LOYALTY
}

\author{
Didit Darmawan \\ Universitas Mayjen Sungkono Mojokerto \\ dr.diditdarmawan@gmail.com
}

\begin{abstract}
The marketing literature has acknowledged that consumers are looking for brands that provide a good, unique and unforgettable experience. The success of a brand in the long run depends greatly on the number of loyal consumers who regularly buy on a particular brand. This study aims to analyze and discuss the effect of brand experience on brand trust and brand loyalty. The research method used is a survey. The population in this study were consumers of Zwitsal products as a product for babies but used among adults. Respondents were set at 100 people. The sampling method used in this study is a non probability sampling method. The technique used is convenience sampling where respondents are based on anyone who by chance is seen as fulfilling the requirements as a data source. The analytical tool used is linear regression with the help of SPSS 24.0 for Windows software. The results show that brand experience has a significant positive effect on brand trust, and brand experience has a significant positive effect on brand loyalty.
\end{abstract}

Keywords: Brand Experience, Brand Trust, Brand Loyalty.

\section{INTRODUCTION}

Today most of the leading companies develop customer loyalty and retention programs. In addition to consistently offering high value and satisfaction, marketers can use certain marketing tools to develop stronger bonds with consumers. One of the well-known manufacturers Unilever has the Zwitsal brand that focuses on the target market among infants and children. In Indonesia, there are already many producers involved in the target market who create similar products with almost the same benefits. Seeing these conditions, competition between producers occurs to develop marketing strategies that can include loyal and widespread consumers. To make loyal consumers, of course, requires a long process, especially to create strong brand relationships with consumers. Making consumer loyalty to the brand become one of the key keys to excellence when competing. The company realizes that loyal customers benefit companies because they can save marketing costs (Aykac et al., 2017). 
The main thing that relates to loyal consumers is from brand experience. Consumer experience of brands has an important role in building consumer trust in the brand. Trust is a very important factor for building loyalty. Not only does it affect loyalty, brand experience can also involve consumer emotional ties, where consumers trust the brand by being marked by attraction and positive influence, and can be regarded as satisfaction with the brand. Brand experience is the basis of the assessment of consuming the previous brand at the time of the first purchase. From the experience that has been obtained, it will lead to trust and will carry out consumption actions in a sustainable manner. When consumer expectations are met, consumers will tend to trust and become loyal customers to a brand.

Leading companies continue to strive to retain customers. Most studies show that the higher the level of customer satisfaction, the higher the loyalty of consumers, which will result in better company performance. A superior company aims to satisfy customers by only promising what they give and then giving more than they promise. Satisfied consumers not only repeat purchases, they will become actors of word of mouth who tell others about their good experiences with the product. Based on the background described earlier, the purpose of this study was to observe the effect of brand experience on brand trust and brand loyalty.

Based on the discussion of the previous section and the theoretical and empirical studies presented earlier, the conceptual framework of this study is shown in Figure 1. The research conceptual framework shows two hypotheses in this study, namely brand experience has a significant positive effect on trust; and brand experience has a significant positive effect on brand loyalty.

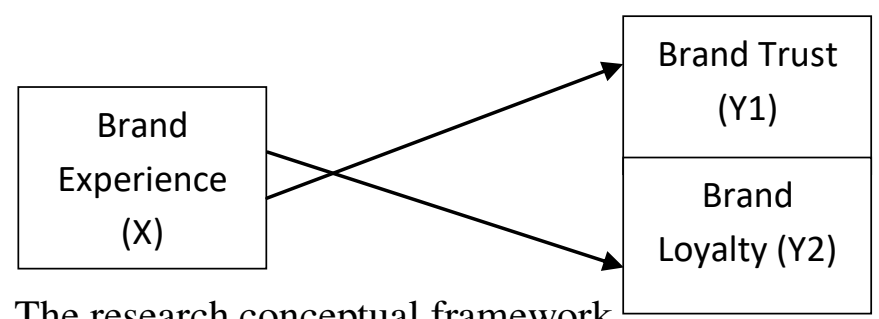

Figure 1. The research conceptual framework 


\section{RESEARCH METHODS}

The research was conducted in the city of Surabaya on the Zwitsal brand. In this study, respondents were consumers of Zwitsal products among adults. Respondents were set at 100 people. The analytical tool used is linear regression. Regression analysis is used to determine how much influence brand experience has on brand trust and brand loyalty. The sampling method used in this study is a non probability sampling method. The technique used is convenience sampling where respondents are based on anyone who by chance is seen as fulfilling the requirements as a data source. The conditions stipulated are respondents are consumers of Zwitsal products who live in the city of Surabaya

\section{Brand Experience $(\mathrm{X})$}

This variable is defined as a set of affective responses, cognitions and behaviors derived from stimuli given by brand attributes such as design and brand identity, packaging, communication, and environment (Brakus et al., 2009). The indicators are (a) the brand has been able to arouse emotions; (b) the brand has succeeded in attracting sensors from the five senses; (c) the brand makes for thinking; (d) the brand causes physical action; and (e) raises the desire to know more about the brand.

2. Brand Trust (Y1)

Brand trust is defined as a feeling of security that users feel as a result of their interaction with a brand, which is based on the perception that the brand is reliable and responsible for the interests and safety of consumers (Delgado, 2003). The indicator is brand reliability and interest in the brand. Brand reliability (brand reliability) is based on consumer confidence that the product is able to meet expectations. Brand intentions are consumer beliefs that the brand is able to prioritize the interests of consumers when problems in product consumption appear unexpectedly.

3. Brand Loyalty (Y2)

This variable is interpreted as the willingness of brand users to make repeated purchases regularly and buy between product lines and services, refer to others and have the power to ignore the temptations of other brands' offers (Griffin, 
2002). The indicator is the level of preference (how much consumers believe in a particular product or service) and the perceived level of product differentiation (how significantly consumers distinguish certain products or services and other alternatives).

Based on the problem, objectives and hypothesis of the study, this study uses statistical methods, namely linear regression analysis techniques that are processed with SPSS 24 program. Before testing the hypothesis by using linear regression analysis techniques, some tests should be done such as testing validity and reliability and testing assumptions. classic.

\section{RESEARCH RESULTS AND DISCUSSION}

Analysis of the results of the study begins by examining the measurement scale, in this study which will be used for regression analysis through the SPSS 24 program. In this method of data analysis the author tries to describe the validity and reliability test tools, classic assumption test, $\mathrm{F}$ test, $\mathrm{t}$ test. Based on the results of calculations using SPSS the results are shown in Table 1.

Table 1. Reliability Test

\begin{tabular}{|c|c|c|}
\hline Variables & N of Item & Cronbanch's Alpha \\
\hline Brand Experience (X) & 10 & 0.874 \\
\hline Brand Trust (Y1) & 6 & 0.758 \\
\hline Brand Loyalty (Y2) & 8 & 0.824 \\
\hline
\end{tabular}

From the brand experience reliability test $(\mathrm{X})$, it can be seen that the cronbach's alpha value of 0.874 is stated as valid. From reliability test (Y1) it can be seen that the cronbach's alpha value is 0.758 with 6 statements declared valid. From brand loyalty reliability test (Y.2) it can be seen the cronbach's alpha value of 0.824 with 8 statements declared valid.

Based on the results of calculations using SPSS, results of classical assumption test from brand experience $(\mathrm{X})$ on trust $(\mathrm{Y} 1)$ are obtained. As in Figure 2 . 


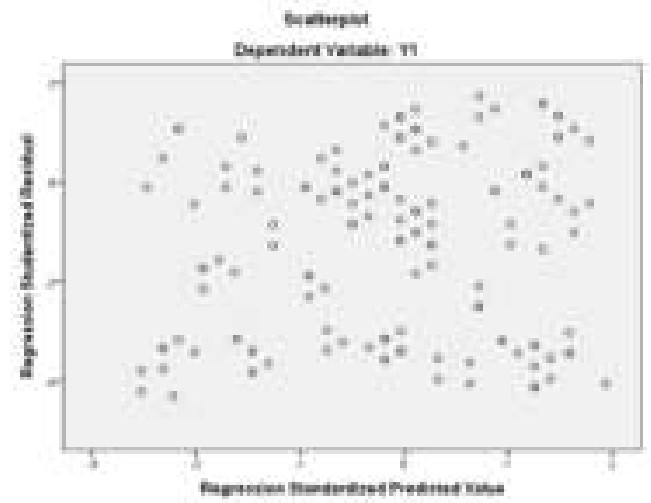

Figure 2 Scatterplot Dependent Variable Source : Output SPSS

Figure 2. shows that the points on the scatterplot are scattered and are in each section on the $\mathrm{Y}$ axis. Thus it can be concluded that there is no heteroscedasticity.

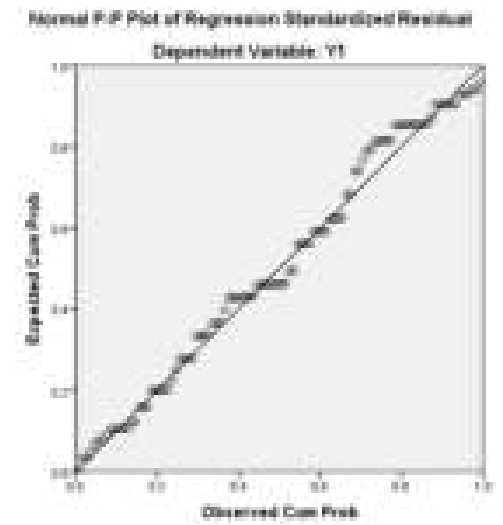

Figure 3.

Normal Probability Plot

Source : Output SPSS

Figure 3 shows that the points follow a diagonal line. The normal distribution will form a diagonal straight line and ploting the data will be compared with the normal line. Thus it can be stated that data distribution is normal. Next is testing the research hypothesis. Based on the results of calculations using SPSS the results are shown in Table 2. 
Table 2. Coefficients ${ }^{\mathrm{a}}$ ( $\mathrm{t}$ Test $)$

\begin{tabular}{|c|c|c|c|c|c|c|c|}
\hline \multirow[b]{2}{*}{ Model } & \multicolumn{2}{|c|}{$\begin{array}{c}\text { Unstandardized } \\
\text { Coefficients }\end{array}$} & \multirow{2}{*}{$\begin{array}{c}\text { Standardized } \\
\text { Coefficients } \\
\text { Beta }\end{array}$} & \multirow[b]{2}{*}{$\mathrm{t}$} & \multirow[b]{2}{*}{ Sig. } & \multicolumn{2}{|c|}{$\begin{array}{c}\text { Collinearity } \\
\text { Statistics }\end{array}$} \\
\hline & B & $\begin{array}{c}\text { Std. } \\
\text { Error }\end{array}$ & & & & Tolerance & VIF \\
\hline $1 \quad$ (Constant) & .275 & 2.320 & & .118 & .906 & & \\
\hline$X$ & .599 & .037 & .853 & 16.150 & .000 & 1.000 & 1.000 \\
\hline
\end{tabular}

a. Dependent Variable: Y1

Source : output SPSS

From Table 2. it can be seen that independent variable of brand experience (X) has a significant effect on dependent variable of brand trust (Y1). From the results of the calculation of Table 2 . the resulting regression equation is $(\mathrm{Y} 1)=$ $0.275+0.599(\mathrm{X})$

Calculation results Table 2 of the previous linear regression equation model shows that the influence of brand experience as the independent variable on brand trust (Y1) as the dependent variable. By doing $t$ test, the hypothesis which states that brand experience has a partially significant effect on brand trust, can be verified.

Table 3. $\operatorname{ANOVA}^{\mathrm{a}}(\mathrm{F}$ Test $)$

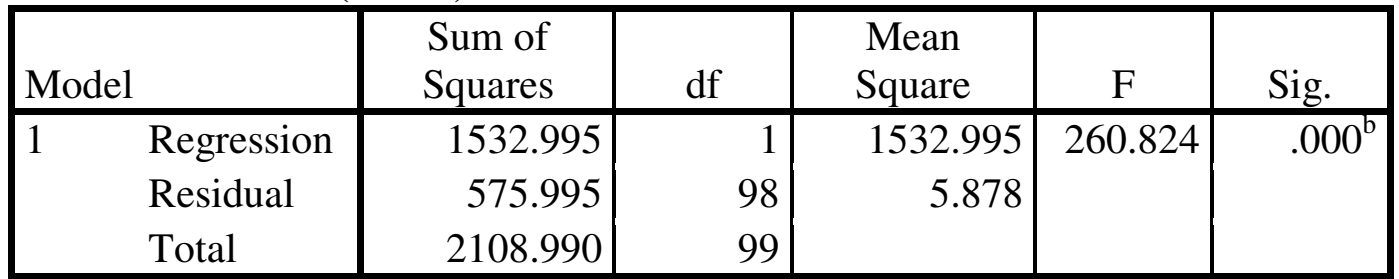

a. Dependent Variable: Y1

b. Predictors: (Constant), X

Source : output SPSS

As an additional result from the results of testing the research hypothesis the $\mathrm{F}$ test was carried out. This $\mathrm{F}$ test is done from the results of the calculation of the data in Table 3. It can be seen that the value of the F statistic is 260.824 with a probability of 0.000 , this means that at the p-value with level $\alpha=0.05$ it can be stated that the brand experience has a significant influence on brand trust (Y1). 
Table 4. Model Summary ${ }^{\mathbf{b}}$

\begin{tabular}{|l|r|r|r|r|r|}
\hline Model & \multicolumn{1}{|c|}{$\mathrm{R}$} & R Square & $\begin{array}{c}\text { Adjusted R } \\
\text { Square }\end{array}$ & $\begin{array}{c}\text { Std. Error of } \\
\text { the Estimate }\end{array}$ & $\begin{array}{c}\text { Durbin- } \\
\text { Watson }\end{array}$ \\
\hline 1 & $.853^{\mathrm{a}}$ & .727 & .724 & 2.424 & 1.550 \\
\hline
\end{tabular}

a. Predictors: (Constant), $\mathrm{X}$

b. Dependent Variable: Y1

Source : output SPSS

Based on the results of the calculation of Table 4 the $\mathrm{R}$ coefficient of 0.853 indicates a strong correlation between the independent variable and the dependent variable. The determination coefficient (R2) is 0.727 and the adjusted $\mathrm{R}$ squared of 0.724 shows that the regression model of the brand experience independent variable $(\mathrm{X})$ has contributed $72.7 \%$ to the dependent variable form of brand trust (Y1), while the remaining $27.8 \%$ is determined by other variables.

Next to the influence of brand experience (X) on brand loyalty (Y.2). Based on the results of calculations using SPSS results obtained from the classical assumption test as in Figure 4.

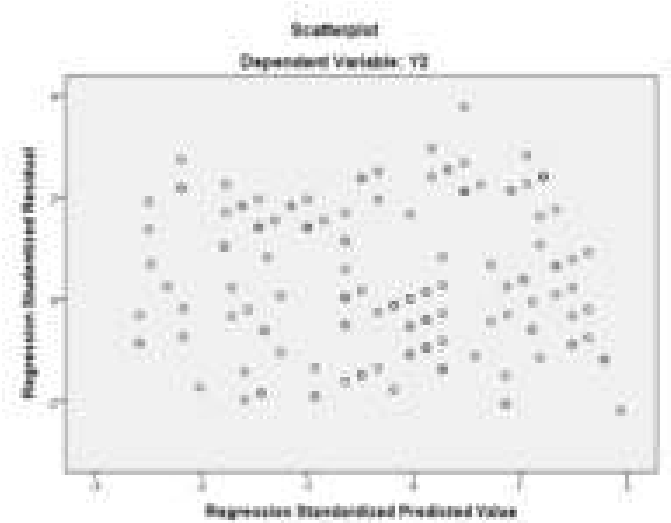

Figure 4. Scatterplot Dependent Variable Source : Output SPSS

Figure 4. shows that the points on the scatterplot are scattered and are in each section on the Y axis. Thus it can be concluded that there is no heteroscedasticity. 


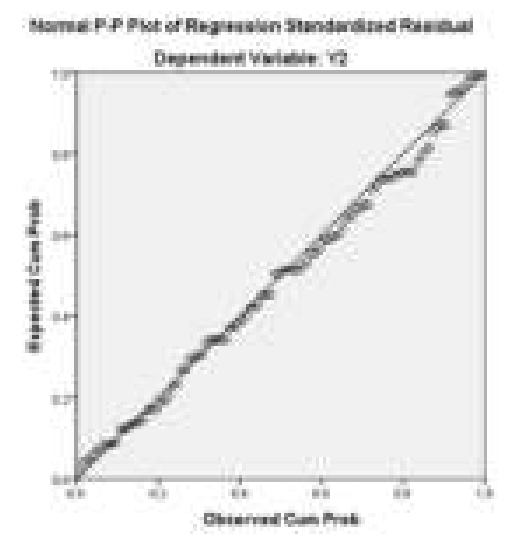

Figure 5. Normal Probability Plot

Source : Output SPSS

Figure 5 shows that the points follow a diagonal line. The normal distribution will form a diagonal straight line and ploting the data will be compared with the normal line. Thus it can be stated that data distribution is normal. Based on the results of calculations using SPSS the results are shown in Table 5.

Table 5. Coefficients $\mathbf{s}^{\mathrm{a}}(\mathrm{t}$ Test $)$

\begin{tabular}{|c|c|c|c|c|c|c|c|}
\hline \multirow[b]{2}{*}{ Model } & \multicolumn{2}{|c|}{$\begin{array}{c}\text { Unstandardized } \\
\text { Coefficients }\end{array}$} & \multirow{2}{*}{$\begin{array}{c}\text { Standardized } \\
\text { Coefficients } \\
\text { Beta } \\
\end{array}$} & \multirow[b]{2}{*}{$\mathrm{t}$} & \multirow[b]{2}{*}{ Sig. } & \multicolumn{2}{|c|}{$\begin{array}{l}\text { Collinearity } \\
\text { Statistics }\end{array}$} \\
\hline & B & $\begin{array}{l}\text { Std. } \\
\text { Error }\end{array}$ & & & & Tolerance & VIF \\
\hline $\begin{array}{ll}1 & \text { (Constant) } \\
& \mathrm{X}\end{array}$ & $\begin{array}{r}.745 \\
.762\end{array}$ & $\begin{array}{r}1.747 \\
.028\end{array}$ & .940 & $\begin{array}{r}2.143 \\
27.295\end{array}$ & $\begin{array}{l}.035 \\
.000\end{array}$ & 1.000 & 1.000 \\
\hline
\end{tabular}

a. Dependent Variable: Y2

Source : output SPSS

From Table 5 it can be seen that brand experience $(\mathrm{X})$ has a significant effect on brand loyalty (Y2). From the results of the calculation of Table 3 the resulting regression equation is $(\mathrm{Y} 2)=3.745+0.762(\mathrm{X})$.

Calculation results Table 5 the previous multiple linear regression equation model shows that there is an influence of brand experience as an independent variable on brand loyalty (Y2) as a dependent variable. By doing the 
t test, the hypothesis that brand experience has a partially significant effect on brand loyalty can be verified.

Table 6. $\mathbf{A N O V A}^{\mathbf{a}}(\mathrm{F}$ Test $)$

\begin{tabular}{|ll|r|r|r|r|r|}
\hline \multicolumn{2}{|l|}{ Model } & $\begin{array}{c}\text { Sum of } \\
\text { Squares }\end{array}$ & df & Mean Square & F & Sig. \\
\hline 1 & Regression & 2484.013 & 1 & 2484.013 & 745.020 & $.000^{6}$ \\
& Residual & 326.747 & 98 & 3.334 & & \\
& Total & 2810.760 & 99 & & & \\
\hline
\end{tabular}

a. Dependent Variable: Y2

b. Predictors: (Constant), $\mathrm{X}$

Source : output SPSS

As an additional result from the results of testing the research hypothesis was analyzed through the $\mathrm{F}$ test. This $\mathrm{F}$ test is done from the results of the calculation of the data in Table 6 . It can be seen that the value of the F statistic is 745,020 with a probability of 0,000 , this means that at the p-value with level $\alpha=$ 0.05 it can be stated that brand experience has a significant effect on brand loyalty (Y2).

Table 7. Model Summary ${ }^{\mathbf{b}}$

\begin{tabular}{|l|r|r|r|r|r|}
\hline Model & \multicolumn{1}{|c|}{$\mathrm{R}$} & R Square & $\begin{array}{c}\text { Adjusted R } \\
\text { Square }\end{array}$ & $\begin{array}{c}\text { Std. Error of } \\
\text { the Estimate }\end{array}$ & $\begin{array}{c}\text { Durbin- } \\
\text { Watson }\end{array}$ \\
\hline 1 & $.940^{\mathrm{a}}$ & .884 & .883 & 1.826 & 1.942 \\
\hline
\end{tabular}

a. Predictors: (Constant), $\mathrm{X}$

b. Dependent Variable: Y2

Source : output SPSS

Based on the results of the calculation of Table 7 the $R$ coefficient of 0.940 indicates a strong relationship between the independent variables and the dependent variable. The coefficient of determination (R2) of 0.884 and the adjusted $\mathrm{R}$ squared of 0.883 indicate that this regression model whose independent variable brand experience $(\mathrm{X})$ has contributed $88.4 \%$ to the dependent variable, brand loyalty (Y2), while the remaining $11.6 \%$ is determined by other variables.

From the analysis of the results of the study, confirmation is needed on previous research and the implications for managerial actions. 
The results of the study state that brand experience has a significant positive effect on brand trust. These results are related to the results of previous studies (Naggar and Noha, 2017; Chinomona, 2013; Sahin et al., 2011; Meyer and Schwager, 2007; Widow and Yburra, 2006; Flavian and Guinaliu 2006; Kim, 2005). Brand trust as the main mediator for long-term relationships and leads to brand loyalty. A consumer who believes in a brand is more willing to remain loyal to a product and is willing to pay a high price. The higher consumer confidence, the higher the loyalty. The existence of trust turns out to be more satisfying for consumers to engage in long-term relationships (Gronross, 2001). The implication is that management needs to consider producing new brands, expanding lines, adding new privileges (Kotler and Keller, 2009). Consumers who have a good and satisfied previous brand experience will create a strong sense of trust to remain loyal and will still try new products with the same brand from the company.

Another result of this study is that brand experience has a significant positive effect on brand loyalty. These results are related to the results of previous studies (Rajumesh, 2014; Sahin et al., 2011; Brakus et al., 2009; Ha and Helen, 2005; Zarantenello and Schmitt, 2000). The importance of the consumer experience of the brand in long-term memory and that will affect the brand and will further lead to brand loyalty. The implication is that management can develop cooperation with partners and related parties to strengthen the company's credibility (Morgan and Hunt, 1994). By working together will expand market share, to reap greater profits and make consumers more satisfied and loyal, they will tell others about their experiences with these products and will open up opportunities to get new consumers.

\section{CONCLUSIONS}

The results of the study show that brand experience has a significant positive influence on brand trust. In addition, the results of the study show that brand experience has a significant positive influence on brand loyalty. The results of the study suggest to improve the brand quality of a product to gain consumer trust and to attract new consumers. In addition, it can also look for new references 
and ideas for processing products so that the products produced are more diverse, with quality products that meet consumer expectations and adhere to certain principles. It is also accompanied by paying attention to efforts to improve emotional relationships that are better and closer to consumers, and improve bad experiences that might have happened to consumers through effective governance of customer service.

\section{REFERENCES}

Aleman-Manuera, Jose, Luis., Elena Delgado-Balester \& Maria Jesus YagueGuillen. 2003. "Development and Validation of Brand Trust Scale". International Journal of Market Research. Vol.45, No.1, Pp.35-53

Aaker, David, A. 1991. Managing Brand Equity: Capitalizing on the Value of a Brand Name. New york. the Free Press.

Aykac, S, Aydin, S, Ates, M \& Cetin, A.T. 2009. "Effect of Service Quality on Customer Satisfaction and Customer loyalty : Example of Marmara University Hospital". International Congress on Performance and Quality in Health. No.3, Pp.19-21. Turkey: Antalya.

Brakus, J.J., Schmitt, B.H., Zarantonello, L. 2009. "Brand Experience: What is it? How is it Measured? Does it Affect Loyalty". Journal of Marketing, Vol.73, No.3, Pp. 52-68.

Chinomona, Richard. 2013. "The Influence of Brand Experience on Brand Satisfaction, Trust and Attachment in South Africa". International Business \& Economics Research Journal. Vol.12, No.10, Pp.1303-1316.

Chaudhuri, A. \& Holbrook, B. M. 2001. The Chain of Effect from Brand Trust and Brand Affects to Brand Loyalty. Journal of Marketing. Vol.65, Pp.8193

Delgado-Ballester, Elena and Munuera-Aleman, J. L. 2005. "Does Brand Trust Matter to Brand Equity?". Journal of Product and Brand Management. Vol.14, No.3

Delgado-Ballester, Elena, Munuera-Aleman, Jose Louis \& Yague-Guillen, Maria Jesus. 2003. Development and Validation of A Brand Trust Scale", International Journal of Market Research, Vol. 45, No.1, pp. 35-53

Ercis, A., Unal, S., Candan, F. \& Yildrim, H. 2012. "The Effect of Brand Satisfaction, Trust and Brand Commitmen on Loyalty and Purchase Intention”. Procedia - Social and Behavioral Science. Vol.58, Pp.13951404.

Flavian, C. \& Guinaliu, M. 2006. "Customer Trust, Perceived Security and Privacy Policy: Three Basic Elements of Loyality to a Web Site". Industrial Management \& Data System. Vol.106 No.5, Pp.601-620.

Griffin, Jill. 2002. Customer Loyalty : How to Earn It, How to Keep It? John Wiley \& Sons Inc, New York, United States

Gronross, C. (2001). Service Management and Marketing. $2^{\text {nd }}$ ed. New York: Willey. 
Gabriano \& Johnson, S. Mark. 1999. "The Different Roles of Satisfaction, Trust and Commitmen in Customer Relationship". Journal of Marketing. Vol.63, Pp.70-87

Ha, Youl-Hong \& Helen, Perks. 2005. "Effect of Consumer Preception on Brand Experience on the Web: Brand Familiarity Satisfaction and Brand Trust". Journal of Consumer Behavior. Vol.4, No.6, Pp.438-452.

Janda, S. \& Ybarra, A. 2006. "Do Product and Consumer Characteristics Affect the Relationship Between Online Experience and Customer Satisfaction?". Journal of Internet Commerce. Vol.4 No.4, Pp. 133-151.

Kotler, Philip dan Kevin dan keller. 2009. Manajemen Pemasaran. Jilid 1. Edisi 11. Terjemahan oleh. Jakarta: Pearson Education Asia dan Prenhalindo

Kim H. 2005. "Consumer Profile of Apparel Product Involvement and Values". Journal of Fashion Marketing and Management. Vol.9 Pp.207-220.

Meyer, C. \& Schwager, A. 2007. "Understanding Customer Experience". Harvard Business Review. Vol.85, No.6, Pp. 116-26, 157.

Oliver, Richard, L . \& rust, roland, T. 1997. "Customer delight: foundations, finding, and managerial insight”. Journal of Retailing. Vol.73. No.3, Pp.311-336

Rajumesh, Sivaraja. 2014. "The Impact of Consumer Experience on Brand Loyalty: The Mediating Role of Brand Attitude". International Journal of Management and Social Science Research (IJMSSR). Vol.3, No.1, Pp.7379

Sahin, Azize., Cemal, Zehir \& Hakan, Kitapci, A. 2011. "The Effect of Brand Experience, Trust and Satisfaction on Building Brand Loyalty; An Empirical Research on Global Brands". International Strategic Management Conference. Vol.24, Pp. 1288-1301.

Schau, J. H., Muniz, M. A. \& Arnould, J. E. 2009. "How Brand Community Practices Create Value" . Journal of Marketing. Vol.73, No.5, Pp.30-51.

Wang, Y, D. \& Emurian, H. H. 2005. "An Overview of Online Trust: Concepts Computers in Human Behavior”. Vol.21, No.1, Pp.105-125

Zarantenello, Lia \& Schmitt, Bernd H. 2000. "Using the Brand Experience Scale to Profile Consumer and Predict Consumer Behavior". Brand Management. Vol.17, no.7, Pp.532-540 